GEOGRAFICKÝ ČASOPIS / GEOGRAPHICAL JOURNAL 72 (2020) 1, 05-25

DOI: https://doi.org/10.31577/geogrcas.2020.72.1.01

\title{
KDE SA CHODÍ VOLIŤ? FAKTORY OVPLYVŇUJÚCE GEOGRAFICKÉ ROZLOŽENIE VOLEBNEJ ÚČASTI V SLOVENSKÝCH PARLAMENTNÝCH VOL'BÁCH
}

\author{
Dominik Kevický*, Petr Daněk* \\ * Masarykova univerzita, Př́rodovědecká fakulta, Geografický ústav, \\ Kotlářská 2,61137 Brno, Česká republika,423695@mail.muni.cz; danek@sci.muni.cz
}

\begin{abstract}
Where do voters appear at ballots? Factors influencing the geographical distribution of voter turnout in Slovak parliamentary elections

Electoral results are significantly influenced by voter turnout, and the explanation of differences in turnout has received considerable academic attention. However, a systematic investigation of the geography of voter turnout in Slovakia has not been conducted yet. The objective of the study is, first, to present a map of voter turnout in parliamentary elections in Slovakia and the changes it has undergone since 1998, and, second, to identify social factors which can potentially explain geographical variability visible on the map. The particular objective was to test the predictive ability of five voter turnout theories in the conditions of Slovak society. The empirical analysis was based on multiple regression analysis and additional statistical analyses. The results have shown a deepening of geographical differences in turnout with time, and a transition of interpretative frameworks, from the theory of disenchantment, relevant in the $1990 \mathrm{~s}$, to theories of modernization and socioeconomic status, more relevant in the 2010s. At the same time, the effect of indirect mobilization and habitual voting was proved significant throughout the whole period of 1998 to 2016.
\end{abstract}

Key words: voter turnout, parliamentary elections, geographical variability, theories of voter turnout, regression analysis, Slovakia

\section{ÚVOD: PRÍSTUPY K VOLEBNEJ PARTICIPÁCII}

„Chod’te volit'!“ vyzývajú pred vol'bami kandidáti zo všetkých strán politického spektra. Tesnost' výsledkov mnohých hlasovaní, ako boli napríklad americké prezidentské vol'by v rokoch 2000 a 2016 alebo hlasovanie o brexite, pritom ukazuje, že práve účast', resp. rozdielna miera mobilizácie voličov z rôznych regiónov a rôznych sociálnych skupín, môže významne ovplyvnit' celkový výsledok volieb. Inými slovami, apel „Chod'te volit!‘“ je v spoločnosti akceptovaný nerovnomerne (Lijphart 1997). Vzhl’adom na význam voličskej participácie pre výsledok volieb je jej štúdiu venovaná značná pozornost', a to do takej miery, že je možné písat' o existencii multidisciplinárneho odboru ,štúdium volebnej participácie“.

Tento výskum začal serióznejšie v 40. rokoch 20. storočia na Kolumbijskej univerzite v New Yorku. Paul Lazarsfeld a jeho kolegovia sériou výskumov verejnej mienky zist'ovali, ako sa $\mathrm{v}$ mesiacoch pred vol'bami utvára prístup voličov $\mathrm{k}$ hlasovaniu, a skúmali, ako je tento proces ovplyvnený existujúcimi postojmi, očakávaniami, osobnými kontaktmi alebo príslušnost'ou k rôznym sociálnym skupinám a organizáciám (Blais 2000). Poukázali na klúčcovú úlohu kategórií, ako je vzdelanie, sociálno-ekonomický status alebo vek, rozširujúcich škálu príležitostí, ktoré jednotliví voliči môžu účastou na vol'bách získat'. Preto je tento sociologický prístup k participácii označovaný ako model zdrojov (resource model - Brady et al. 1995 a Schulz-Herzenberg 2019). Druhá tradičná škola volebného správania vznikla 
v 50. rokoch na Michiganskej univerzite a prvé závery publikovala v klasickej monografii The American Voter (Campbell et al. 2000). Prístup tejto školy je viac sociálno-psychologický. Nezavrhuje síce vplyv sociálnych kategórií, s ktorými pracuje kolumbijská škola, ale tvrdí, že tie stoja iba na začiatku ret'azca príčin a majú len nepriamy vplyv na psychologické procesy, ktorých výsledkom je rozhodnutie íst' alebo neíst' volit' (Brady et al. 1995). Model psychologického konania (psychological engagement model) michiganskej školy zdôrazňuje vplyv politických záujmov, angažovanosti i straníckej identifikácie na participácii, ale v zásade nevysvetl'uje, prečo niektorí l'udia nakoniec volit' idú a iní nie (Blais 2000 a SchulzHerzenberg 2019). Tretia skupina prístupov vyzdvihuje rolu mobilizačných agentov, akými sú záujmové skupiny, cirkvi, politické strany a iné sociálne siete. Rozhodnutie zúčastnit' sa volieb je podl'a týchto prístupov ovplyvnené l'ud'mi a skupinami, s ktorými sa stretávame v každodennom živote (Franklin 2004). K týmto prístupom je možné radit' mobilizačné kampane politických strán a kandidátov. Geografi skúmajúci nerovnomerný vplyv politických kampaní v tomto kontexte píšu o efekte kampane (vid' Johnston 1987 a Pattie et al. 2019). Významným a často skúmaným mobilizačným agentom sú média (Norris 2000). Sttvrtá skupina prístupov je založená na teórii racionálnej vol'by (rational choice theory) a zdôrazňuje užitočnost' samotného aktu hlasovania pre voličov. Ak sú náklady vo forme času potrebného na získanie informácií o kandidátoch alebo o samotnej účasti na hlasovaní vyššie než očakávané zisky, ako je napr. pravdepodobnost' ovplyvnit' výsledok volieb, volič zostane doma (Blais 2000, Franklin 2004 a Schulz-Herzenberg 2019). Predstavu, že výšku volebnej účasti je možné vysvetlit' pomocou modelu založeného na racionálnom rozhodovaní jednotlivcov však spochybňuje paradox hlasovania (paradox of voting), ktorý sformuloval americký ekonóm Anthony Downs už v 50. rokoch 20. storočia. Podl'a neho náklady na hlasovanie, aj ked' sú nízke, takmer vždy prevážia nad očakávanými benefitmi, pretože pravdepodobnost', že hlas voliča prispeje rozhodujúcim spôsobom k zvoleniu vybranej strany alebo kandidáta, je zanedbatel'ná (Fieldhouse 2019, p. 319).

Empirické prístupy k štúdiu volebnej participácie sa výrazne odlišujú tiež z hl'adiska metodológie. Castejšie sú analýzy založené na individuálnych dátach od jednotlivých voličov, získavaných sociologickými prieskumami. Práve pokrok v metódach sociologického prieskumu verejnej mienky v 40. rokoch 20. storočia v USA umožnil vznik empirických štúdií volebnej participácie. Metódy priameho prieskumu verejnej mienky umožňujú nesprostredkovane prepojit' najrôznejšie predpoklady a podmienky (ako je status voliča, očakávania, vplyv kampane atd'.) s výsledkami (vlastné volebné správanie) a sú bežné pri prieskumoch volebného správania na národnej úrovni alebo pre medzinárodné porovnanie. Druhou skupinou sú analýzy založené na agregovaných dátach, ktoré sledujú vzt'ah medzi volebnou účastou v určitej geograficky vymedzenej populácii a demografickými, sociálnymi, ekonomickými a d'alšími vlastnost'ami tejto populácie. Sú zat’ažené tzv. ekologickou chybou, spočívajúcou $\mathrm{v}$ tom, že jednotlivcom prisudzujeme správanie skupiny, čo môže skrývat' príčinné súvislosti. Analýza agregovaných dát však zostáva jedinou možnost'ou tam, kde nemáme dostatok individuálnych dát za menšie územné jednotky, teda vo väčšine geografických analýz volebných výsledkov (napr. Madleňák 2012, Mikuš 2014 a Kostelecký a Krivý 2015).

Ciel'om tejto štúdie je najprv predstavenie „mapy“ nerovnomernej volebnej participácie na Slovensku, aká sa utvárala $\mathrm{v}$ uplynulých dvoch dekádach, a následne interpretácia tejto mapy, motivovaná snahou nájst' podstatné faktory ovplyvňujúce 
rôznu výšku volebnej participácie $\mathrm{v}$ rôznych miestach a vývoj týchto faktorov $\mathrm{v}$ čase. Zvláštna pozornost' bude $\mathrm{v}$ tejto interpretácii venovaná schopnosti hlavných teórií volebnej participácie vysvetlit' správanie slovenských voličov. Základnou geografickou jednotkou analýzy sú obce, čo umožňuje porovnat' nielen horizontálny rozmer geografickej diferenciácie (rozdiely medzi regiónmi), ale aj rozmer vertikálny (medzi vel'kostnými skupinami obcí). Pozornost' venujeme iba parlamentným vol'bám.

$\mathrm{V}$ nasledujúcich častiach predstavíme hlavné doterajšie poznatky o geografii volebnej účasti na Slovensku, ktoré vyplynuli z publikovaných analýz a stručne charakterizujeme hlavné relevantné teórie volebnej účasti, ktorých vypovedajúcu schopnost' v slovenskom kontexte budeme neskôr empiricky overovat'. Dalšia čast' prezentuje vývoj volebnej účasti na Slovensku v parlamentných vol'bách v rokoch 1998 až 2016, jej regionálnu variabilitu a geografickú nerovnomernost' - teda „mapu“ volebnej participácie. Následná čast' vysvetl'uje metodický postup použitý pre vlastnú empirickú analýzu. Posledné dve časti článku prinášajú diskusiu výsledkov a súhrn zistených poznatkov.

\section{PREHLAD LITERATÚRY}

Podl'a Plešivčáka et al. (2016) nebol na Slovensku uskutočnený dlhodobý a systematický geografický výskum volebnej účasti. Väčšina autorov sa venuje problematike volebnej účasti len ako súčast' celkovej analýzy volieb na Slovensku. Kostelecký (2001) identifikoval okresy Slovenska, v ktorých bola v rokoch 1992 až 1998 vysoká volebná neúčast' a pomocou regresnej analýzy hl'adal faktory, ktoré neúčast' ovplyvnili. Zistil, že volebná účast' bola nízka v okresoch s vysokou mierou kriminality a vysokou priemernou mzdou zamestnancov - čiže v metropolitných oblastiach Bratislavy a Košíc. Krivý (2012) si v rámci analýzy výsledkov volieb do parlamentu v roku 2012 všimol, že medzi rokmi 2010 a 2012 došlo k poklesu volebnej účasti v obciach s vysokým zastúpením mad'arského obyvatel'stva.

Madleňák (2012) skúmal regionálne rozdiely volebnej účasti v štyroch parlamentných vol'bách od roku 1998 do roku 2010. Okresy Slovenska rozdelil do piatich kategórií podl'a toho, aká bola odchýlka volebnej účasti v okrese od priemernej volebnej účasti. Zistil, že celkovo sa v skúmanom období výrazne nemenilo geografické rozloženie volebnej účasti, ale súčasne upozorňuje na pokles volebnej účasti vo východoslovenských okresoch a naopak, na jej nárast v Bratislave a okolí. Madleňák a Pink (2012) analyzovali územia so stabilne vysokou volebnou účast'ou a neúčast'ou v rokoch 1994 až 2010. Poukázali na to, že okresy so stabilnou neúčast'ou tvoria na jednej strane periférne oblasti a na druhej strane vel'komestské prostredie. Podobnú analýzu uskutočnili aj Gyárfášová a Krivý (2013), ktorí analyzovali parlamentné vol'by v rokoch 1990 až 2012. Podotýkajú, že na Slovensku dochádza ku stabilizácii rozloženia volebnej účasti v čase v porovnaní s výkyvmi, ktoré boli charakteristické v 90. rokoch. Tiež konštatujú, že vd'aka tomu, že volebná účast' je vyššia v oblastiach s vyšším sociálno-ekonomickým statusom sa Slovensko posúva ku štandardnému modelu volebnej účasti, ktorý je typický pre západoeurópske demokracie. Mikuš (2014) si tiež všimol dlhodobú stabilitu oblastí s nadpriemernou, respektíve podpriemernou volebnou účast'ou. Zaznamenal, že okresy s dlhodobo podpriemernou volebnou účast'ou majú podobné geografické rozloženie ako miera nezamestnanosti a dlhodobá nezamestnanost'. Rybář et al. (2017) použili na vysvetlenie geografického rozloženia volebnej účasti v parla- 
mentných vol'bách v roku 2016 regresnú analýzu, pričom zistili, že účast' bola vyššia v obciach s lepšou ekonomickou situáciou, vyššou vzdelanost'ou a vyšším podielom l'udí vo veku 65 a viac rokov. Došli k záveru, že volebná účast' je ovplyvnená prítomnost'ou sociálno-ekonomických zdrojov.

Pravdepodobne jedinou prácou, zameranou čisto na účast' vo vol'bách konaných na Slovensku, je článok Mikuša a Gurňáka (2014) venujúci sa volebnej účasti v obciach Košického kraja v rokoch 1999 až 2014. Autori analyzovali zmenu volebnej účasti v rôznych typoch volieb v jednotlivých obciach kraja. Košický kraj sa v rámci Slovenska dlhodobo vyznačuje najnižšou volebnou účast’ou vo všetkých druhoch volieb, pričom volebná neúčast' je podl'a autorov spôsobená viacerými faktormi, napríklad neschopnost'ou politikov, politickými kauzami a pod. Tieto faktory podl'a autorov spôsobili, že v Košickom kraji až v štvrtine obcí dochádzalo ku kontinuálnemu poklesu volebnej účasti v dvoch a viacerých vol'bách za sebou.

Kostelecký a Krivý (2015) skúmali urbánno-rurálne rozdiely volebnej účasti na Slovensku. Zamerali sa na rozdiel v priemernej výške volebnej účasti vo vel'kostných kategóriách obcí a zistili, že vysoká volebná účast' zostáva dlhodobo v najmenších obciach a vedl'a toho postupom času narastala i v najväčších mestách. Zatial' čo v najväčších mestách zohrávajú dôležitú úlohu najmä sociálno-ekonomické charakteristiky, v najmenších obciach ide skôr o zvyk chodit' pravidelne volit' a sociálny tlak, ktorý je vyvíjaný na voličov v rámci komunity, aby sa nemuseli odlišovat' od „normálu“ a neboli ohováraní.

\section{TEÓRIE VOLEBNEJ ÚČASTI}

$\mathrm{V}$ nasledujúcich odsekoch predstavíme teórie, ktorými sa regionálne rozdiely vo výške volebnej účasti najčastejšie vysvetl'ujú.

Teória modernizácie (societal modernization theory) vychádza z predpokladu, že charakteristickým rysom modernej spoločnosti je demokratická forma vlády a participácia na vol'bách je potrebným predpokladom demokracie. Stupeň modernizácie spoločnosti je možné merat' kvantitatívne súborom sociálno-ekonomických indikátorov. Čím je stupeň modernizácie vyšší, tým vyššie nároky sú vytvárané na aktívnu účast' obyvatel'ov v rozhodovacích procesoch (Norris 2002). Preto autori ako Norris (2002) alebo Birch (2003) usudzujú, že čím je pokročilejšia modernizácia spoločnosti, tým je možné predpokladat' vyššiu účast' vo vol'bách. Indikátormi tradične používanými na meranie stupňa modernizácie sú napríklad miera urbanizácie, index ekonomického alebo l'udského rozvoja alebo podiel ekonomicky aktívnych v agrárnom sektore.

Teória sklamaného voliča (theory of disenchanted voting) vysvetluje volebnú účast' pomocou sociálno-ekonomických ukazovatel'ov podobne ako teória modernizácie, avšak ich vplyv interpretuje odlišne. Podnetom pre vznik tejto teórie bola zrejmá neadekvátnost' teórie modernizácie pre vysvetlenie vývoja a regionálnych rozdielov vo volebnej účasti v postsocialistických štátoch. Skutočnost', že štát prešiel obdobím socializmu, znižuje podl'a Kostadinovej (2003) a Packa et al. (2009) volebnú účast' a zároveň špecificky podmieňuje efekt sociálno-ekonomických charakteristík. Nový (2013) podotýka, že špecifiká socialistického rozvoja spôsobili po páde socializmu ekonomické a politické problémy. Preto, aj ked' ukazovatele sociálneho a ekonomického rozvoja na agregovanej úrovni rástli, kvalita života niektorých občanov klesala a tí sa $\mathrm{v}$ reakcii na to rozhodli rezignovat' $\mathrm{z}$ účasti v demokratickom procese. Touto argumentáciou sa teória sklamaného voliča snaží vysvet- 
lit', prečo súčasne s ekonomickým a sociálnym rozvojom volebná účast' v postsocialistických štátoch klesala, zatial' čo teória modernizácie predpokladala jej nárast.

Teória sociálno-ekonomického statusu (socioeconomic status theory), ktorá vychádza priamo z klasickej kolumbijskej školy volebného správania, zahŕňa niekol'ko prístupov, ktoré vysvetl'ujú volebnú účast' pomocou ekonomických a sociálnych charakteristík jednotlivých občanov. Najčastejšie použivanými ukazovatel'mi sú vzdelanie, príjem, typ zamestnania, nezamestnanost', pohlavie či vek osoby. Ciel’om je určit', aké sociálno-ekonomické charakteristiky jednotlivcov ovplyvňujú ich rozhodnutie íst' k vol'bám. Podl'a tejto teórie sa volieb viac zúčastňujú jednotlivci s vyšším sociálno-ekonomickým statusom, pretože majú viac zdrojov (peniaze, schopnosti alebo informácie), vd’aka ktorým sa im znížia náklady na hlasovanie a môžu získat' väčšie zisky z výsledkov hlasovania (Wolfinger a Rosenstone 1980). Kritika teórie sociálno-ekonomického statusu a zdrojov spočíva v tom, že sociálnoekonomické charakteristiky toho vel'a nepovedia o motivácii íst' volit' a často sú len ukazovatel'om iných charakteristík, ktoré ovplyvňujú voličovo správanie.

Teória mobilizácie (mobilization theory) predpokladá, že rozhodnutie íst' alebo neíst' volit' nevychádza len z osobných hodnôt a postojov občanov, ale že je výrazne ovplyvnené aj ich okolím. Teória predpokladá, že voliči sú politicky mobilizovaní, pričom Rosenstone a Hansen (2009) označujú za politickú mobilizáciu proces, pri ktorom kandidáti, politické strany, aktivisti, ale i nepolitické organizácie, ako sú cirkvi, odbory alebo záujmové spolky, presviedčajú občanov, aby išli volit'. Autori rozlišujú dva typy mobilizácie, a to priamu a nepriamu. Za priamu mobilizáciu považujú prípady, v ktorých je potenciálny volič oslovený politickou stranou alebo kandidátmi. $\mathrm{K}$ metódam tejto mobilizácie patria predvolebné mítingy, kampane $\mathrm{v}$ médiách, kontaktovanie voličov telefónom, poštou alebo elektronicky. V prípade nepriamej mobilizácie je človek ovplyvnený l'ud’mi zo svojho okolia. Môže byt' mobilizovaný svojimi priatel'mi, kolegami z práce, susedmi, členmi spolku alebo náboženskej komunity. Dôležitú úlohu môže zohrávat' aj príslušnost' $\mathrm{k}$ určitej národnostnej menšine. Ak má menšina svoje politické zastúpenie, môže to zvyšovat' mobilizáciu jej príslušníkov (Krivý 2012, Szabó a Tátrai 2016). Silno ovplyvňuje rozhodovanie potenciálneho voliča jeho rodina. Viacero štúdí dokladá príklady toho, že ak sa najbližší člen rodiny zúčastnil volieb, tak sa výrazne zvýšila pravdepodobnost', že sa sám občan zúčastní (Vlachová 2012). Linek (2015) uvádza, že volebná účast' je vyššia, ak sú voliči spolu v manželstve, oproti tomu, ak bývajú ako slobodný pár v spoločnej domácnosti. Okrem toho Knack (1992) poznamenáva, že v určitých oblastiach je vd’aka štruktúre a stabilite osídlenia silná sociálna kontrola a tlak na obyvatel'a, aby sa volieb zúčastnil. V prípade neúčasti môže dôjst' až k sociálnemu vylúčeniu obyvatel'a z komunity. Jav sociálnej kontroly je typický najmä pre malé vidiecke obce (Kostelecký a Krivý 2015). Tým sa predpokladá, že v oblastiach s vyšším podielom obyvatel'stva vyznávajúcich nejakú vieru, $v$ oblastiach $s$ vyšším zastúpením národnostnej menšiny a v malých obciach dochádza $\mathrm{k}$ väčšej nepriamej mobilizácii voličov, čím sa zvyšuje volebná účast'.

Teória habituálneho hlasovania (theory of habitual voting) vychádza $\mathrm{z}$ predpokladu, že volič, ktorý sa zúčastnil volieb v minulosti, má väčšiu pravdepodobnost' účasti i v budúcich vol'bách. Aj ked' sa prvé myšlienky o volebnej účasti ako zvyku objavili už v prácach autorov michiganskej školy, vo väčšej miere začala byt' tejto problematike venovaná pozornost' po vydaní štúdie Greena a Shachara (2000). Teória predpokladá, že hlasovanie vo vol'bách obsahuje prvok zvyku. U občana sa 
postupom času vytvára zvyk byt' alebo nebyt' súčast'ou volebného procesu a čím dlhšie sa podiel'a alebo nepodiel'a na hlasovaní, tým sa zvyk zosilňuje. Dôležitou premennou vysvetl'ujúcou volebnú účast' je preto účast' v predchádzajúcich vol'bách. Podl'a Dennyho a Doyla (2009) sa občania zúčastňujú volieb bez ohl'adu na to, či pozitívne hodnotia hlasovanie, alebo či si myslia, že hlasovanie je správna vec. Dôležité je iba to, že voliči majú v pamäti vybudovaný zvyk zúčastňovat' sa volieb. V rámci postsocialistických štátov to možno vidiet' na vysokej volebnej účasti staršieho obyvatel'stva, ktoré si vybudovalo zvyk chodit' volit' v období socializmu, ked' to bolo povinné, a tento zvyk si zachováva aj v súčasnosti (Linek 2013). Nemusí pritom íst' o vol'by rovnakého typu. Kostelecký a Krivý (2015) podotýkajú, že vyššia volebná účast' pri parlamentných vol'bách v malých obciach môže byt' spôsobená vyššou volebnou účast'ou pri vol'bách komunálnych, a tak si občania vytvoria zvyk zúčastňovat'sa akýchkol'vek volieb. Slabinou tejto teórie je to, že nedokáže vysvetlit', prečo sa volieb zúčastňujú prvovoliči, ked'že u nich nie je vytvorený zvyk íst' volit'.

\section{VÝVOJ VOLEBNEJ ÚČASTI NA SLOVENSKU}

Na Slovensku sa od roku 1989 konalo devät' volieb do parlamentu. Najvyššia účast' bola dosiahnutá hned' v prvých demokratických vol'bách po páde komunistického režimu, konaných v roku 1990 (obr. 1). Účast' v týchto vol'bách bola vyššia ako $95 \%$ a v žiadnom okrese neklesla pod $90 \%$. V nasledujúcich vol'bách v roku 1992 klesla účast' o desat' percentuálnych bodov a klesala i nad'alej, s výnimkou volieb v roku 1998, ktoré boli v rámci Slovenska špecifické (Krivý 1999), až dosiahla vo vol'bách v roku 2006 svoje historické minimum $(54,7 \%)$. V niektorých okresoch sa $\mathrm{v}$ týchto vol'bách nezúčastnila ani polovica oprávnených voličov. V posledných troch vol'bách v rokoch 2010, 2012 a 2016 sa volebná účast' ustálila na hodnote mierne pod $60 \%$.

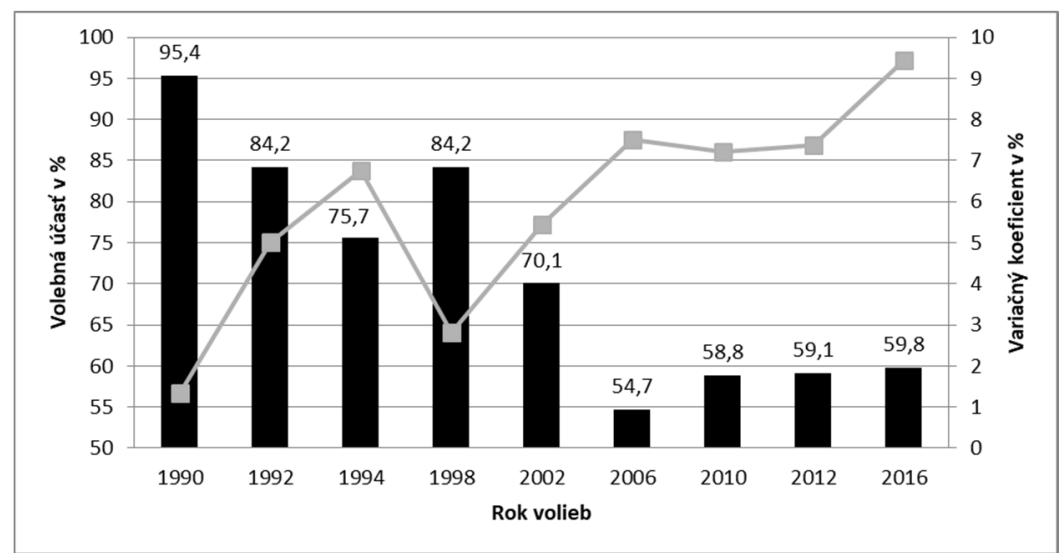

Obr. 1. Vývoj volebnej účasti v parlamentných vol'bách na Slovensku (stípce, os vl’avo) a variačného koeficientu volebnej účasti v okresoch (krivka, os vpravo)

Zdroj dát: Krivý (2016).

$\mathrm{V}$ opačnom trende $\mathrm{v}$ porovnaní $\mathrm{s}$ vývojom volebnej účasti sa vyvíjala úroveň medziregionálnych rozdielov. Na obr. 1 je možné vidiet' vývoj variačného koefi- 
cientu, ktorý vyjadruje celkovú úroveň rozdielov medzi okresmi (bol vypočítaný pre súbor 79 okresov Slovenska, utvorených v roku 1996). Vývoj regionálnej variability je možné zjednodušene interpretovat’ ako postupné prehlbovanie regionálnych rozdielov vo volebnej účasti, od najnižšej úrovne v roku 1990 po najvyššiu v roku 2016. Tento trend bol významné prerušený v roku 1998, ked' sa protimečiarovskej koalícii podarilo mobilizovat' voličov i v okresoch s nižšou účast'ou.

Nárast regionálnej variability potvrdzuje i vývoj medzikrajových rozdielov znázornený na obr. 2. S výnimkou volieb v roku 1998 je zrejmý trend postupnej diferenciácie, čiže vzd'al'ovanie sa väčšiny krajov od slovenského priemeru. Na jednej strane sa vyčleňuje skupina Bratislavského, Žilinského a Trenčianskeho kraja s nadpriemernou a relatívne rastúcou účast'ou, na druhej strane je to skupina Nitrianskeho, Banskobystrického a Prešovského kraja s podpriemernou a relatívne klesajúcou účast’ou. Najväčším „outsiderom“, t. j. krajom z hl'adiska volebnej účasti najviac vzdialeným všetkým ostatným, je Košický kraj s extrémne nízkou účastou. Zatial' čo rozdiel medzi Bratislavským a Košickým krajom bol v roku 1998 nulový, do roku 2010 narástol na 15 p. b. a v roku 2016 to bolo až 23 p. b. Naopak, Trnavský kraj je dlhodobo v rámci Slovenska najtypickejší, s hodnotou pohybujúcou sa vel'mi blízko národného priemeru. Najväčšiu zmenu zaznamenal kraj Bratislavský, v ktorom bola v 90. rokoch najnižšia volebná účast', avšak po roku 2000 tu nastal výrazný nárast a vo vol'bách v roku 2010 a 2016 mal volebnú účast' najvyššiu.

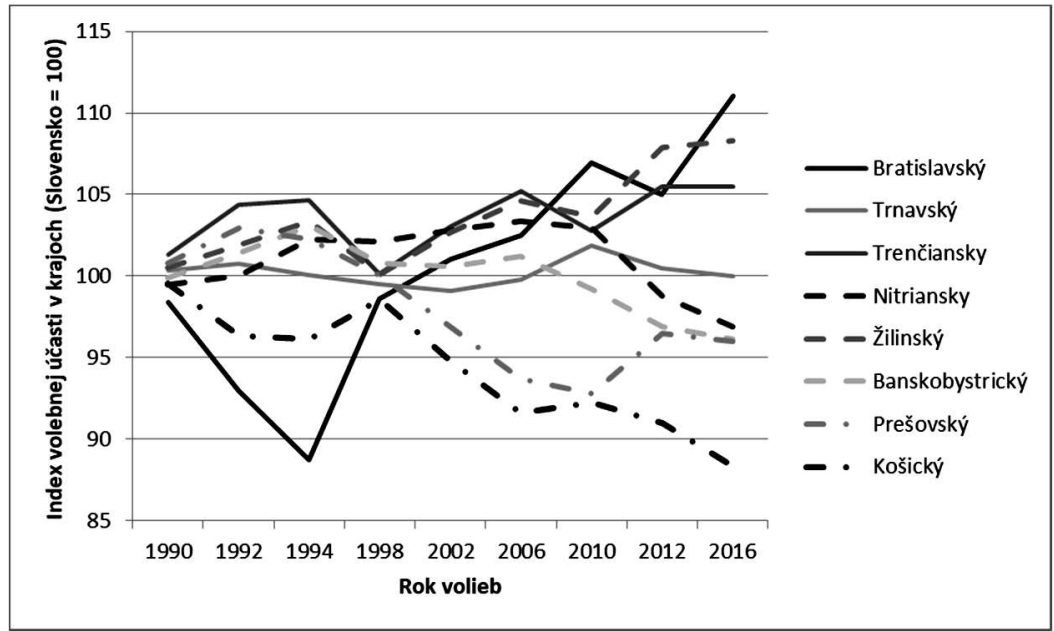

Obr. 2. Index volebnej účasti v krajoch vzhl’adom na republikový priemer

Zdroj dát: Krivý (2016).

Súbežne s prehlbovaním regionálnej variability sa menilo aj geografické rozloženie obcí so stabilne nadpriemernou, respektíve podpriemernou volebnou účast’ou. Tie definujeme ako obce, ktoré mali vo vymedzenom období vždy nadpriemernú, respektíve podpriemernú účast' vzhl'adom na celoslovenský priemer. Vo vol'bách v rokoch 1998 až 2006 sa obce s nadpriemernou volebnou účast'ou nachádzali predovšetkým na západnom a strednom Slovensku, zatial' čo obce s podpriemernou účast'ou sa koncentrovali na Záhorí, Kysuciach, Orave a na východnom 
Slovensku. V rokoch 2010 až 2016 bola nadpriemerná volebná účast' v Bratislave a jej okolí a na strednom Slovensku a súčasne sa takmer vytratili obce s nadpriemernou účast'ou na juhu Slovenska. Obce s podpriemernou volebnou účast'ou zostali koncentrované hlavne na východe Slovenska a zvýšil sa ich počet na juhu Slovenska. Naproti tomu sa zmenšil počet obcí s podpriemernou účast'ou na Záhorí, Orave a Kysuciach (vid' obr. 3 a 4).

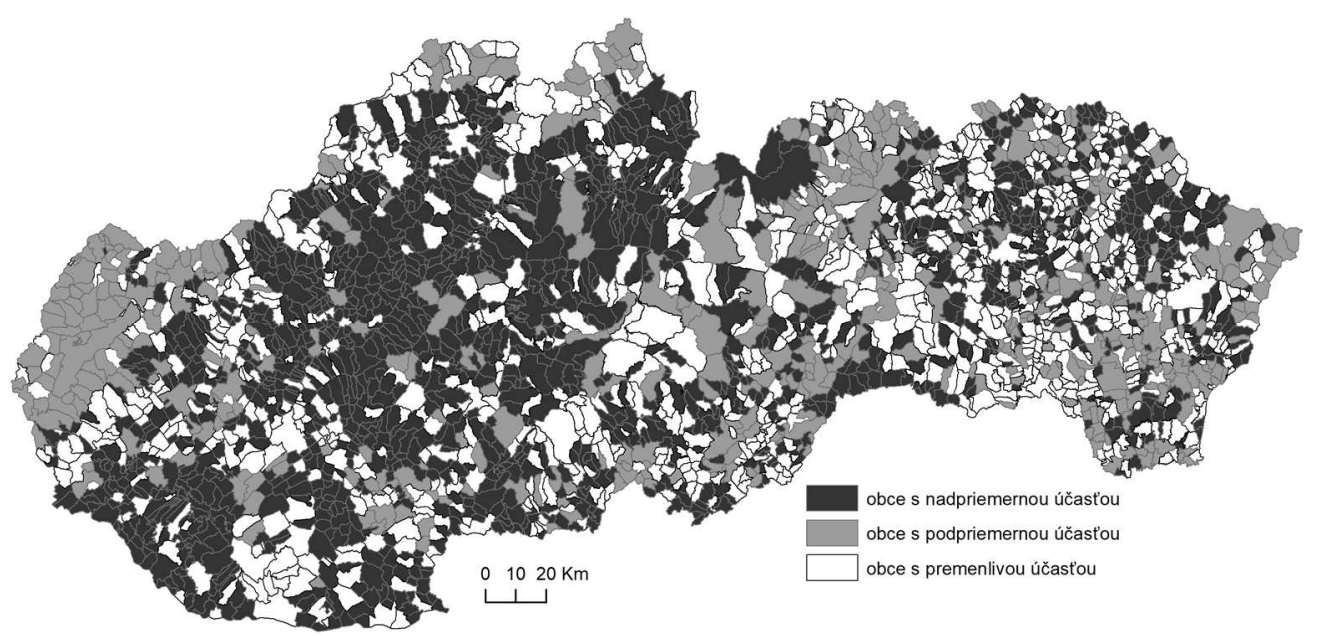

Obr. 3. Obce podl’a volebnej účasti v parlamentných vol'bách v rokoch 1998 až 2006 Zdroj dát: Krivý (2016).

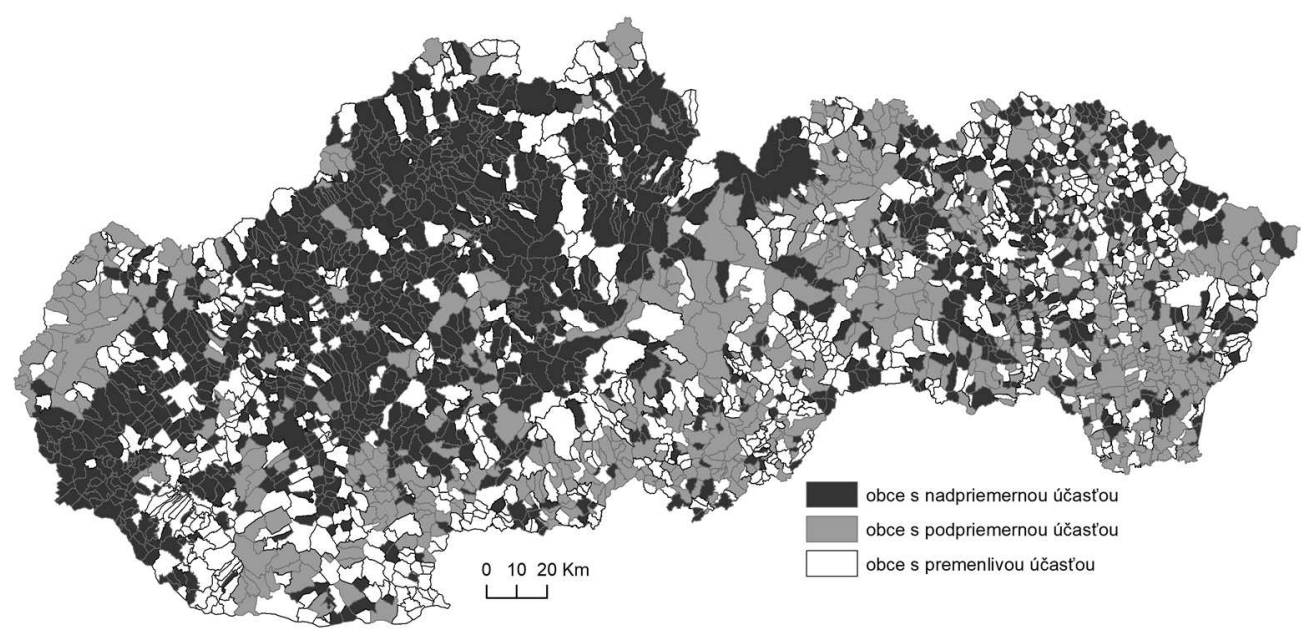

Obr. 4. Obce podl’a volebnej účasti v parlamentných vol’bách v rokoch 2010 až 2016 Zdroj dát: Krivý (2016). 


\section{METODIKA A POUŽITÉ DÁTA}

Pre diskusiu o výpovednej schopnosti predstavených teórií volebnej účasti v podmienkach slovenskej spoločnosti boli formulované tri hypotézy, ktoré, posudzované spoločne, umožnia overit' explanačnú silu týchto teórií a súčasne identifikovat' hlavné faktory podmieňujúce geografické rozdiely vo volebnej účasti. Z diskusie je zrejmé, že tieto teórie nereprezentujú vzájomne sa vylučujúce súbory tvrdení, ale čiastočne sa prekrývajú a v niektorých prípadoch sa opierajú o rovnaké alebo obdobné indikátory, pričom ich význam interpretujú odlišne. Platnost' jednotlivých teórií preto nemožno jednoznačne potvrdit' alebo vyvrátit', môžeme iba posudzovat' ich relatívny prínos $\mathrm{k}$ explanácii vzt’ahu medzi výškou volebnej participácie a sociálnymi, ekonomickými, sídelnými a inými charakteristikami obcí a regiónov Slovenska, ktoré vyjadrujeme pomocou empirických indikátorov. Hypotézy boli formulované tak, aby umožnili čo najlepšie posúdit' vypovedajúcu schopnost' teórií a súčasne aby ich bolo možné overovat' pomocou empirických indikátorov na úrovni obcí. Hypotézy sú označené H1 až H3.

H1: Volebná účast' je vyššia v obciach s vyšším podielom vysokoškolsky vzdelaných obyvatel'ov, s pozitívnym migračným saldom a s nízou mierou nezamestnanosti. Ak by sa ukázala platnost' tejto hypotézy, pre vysvetlenie geografických rozdielov vo volebnej účasti by boli relevantné teória modernizácie a teória sociálnoekonomického statusu. $\mathrm{V}$ prípade negatívneho vzt'ahu účasti a uvedených premenných by bola relevantnejšia teória sklamaného voliča. Premenné zvolené na overenie hypotézy súvisia so stupňom modernizácie spoločnosti, s ktorým pracujú všetky tri uvedené teórie. Pritom je zrejmé, že vzt'ah teórií nie je ambivalentný a platnost' jednej nevylučuje platnost' druhej.

H2: Volebná účast'je vyššia v obciach s menším počtom obyvatelov, s vyšším podielom veriacich obyvatel'ov a syššim podielom obyvatel'ov niektorej národnostnej menšiny. Ciel'om hypotézy je overit', či v podmienkach Slovenska pôsobí nepriamy mobilizačný efekt, podmienený vyšším zastúpením príslušníkov niektorej náboženskej komunity, národnostnej menšiny alebo sociálnou kontrolou v obciach s malým počtom obyvatel'ov.

H3: Volebná účast' je vyššia v obciach s vyšším podielom obyvatel'ov v poproduktívnom veku. Táto hypotéza sa snaží overit' teóriu habituálneho hlasovania, pričom vychádza z toho, že starí l'udia majú vytvorený zvyk chodit' volit' z obdobia socializmu, a tak sa volieb zúčastňujú pravidelne bez ohl'adu na d’alšie podmieňujúce faktory. Veková štruktúra však súvisí aj s inými faktormi, ako je napríklad ekonomická vyspelost', miera urbanizácie alebo migračné saldo, preto je nutné pri interpretácii vzt'ahu medzi účast'ou a vekom zohl'adnit' aj vplyv týchto faktorov.

$\mathrm{Na}$ hodnotenie potenciálneho vplyvu vybraných empirických indikátorov na výšku volebnej participácie v obciach Slovenska sme použili viacnásobnú lineárnu regresiu. Táto metóda umožňuje v súbore nezávislých premenných identifikovat' tie, ktoré štatisticky významne vysvetl'ujú variabilitu závislej premennej - volebnej účasti, zistit', akú čast' variability závislej premennej dokážu nezávislé premenné vysvetlit' a posúdit' relatívnu dôležitost' každej z nezávislých premenných (Rabušic 2004). Použitá bola metóda váženej regresnej analýzy, t. j. premenné, vstupujúce do analýzy, boli vážené vel'kost'ou obce, konkrétne počtom voličov zapísaných vo volebných zoznamoch. Pre poradie vstupu nezávislých premenných do regresného modelu bola zvolená metóda ENTER. Prínos jednotlivých premenných na vysvetlenie variability volebnej účasti sme hodnotili štandardizovaným regresným koefi- 
cientom (beta). Č́m vyššia je absolútna hodnota štandardizovaného koeficientu, tým je daná nezávislá premenná významnejšia pre vysvetlenie variability závislej premennej (Hendl 2012).

Analyzovaná bola volebná účast' v celkom šiestich parlamentných vol'bách, t. j. vo všetkých, ktoré sa na Slovensku konali v rokoch 1998 až 2016. Územnými jednotkami, použitými na analýzu, boli obce. Na zvýšenie váhy populačne vel'kých obvodov boli navyše v regresnej analýze Bratislava a Košice rozdelené na mestské časti. V analýze vzt'ahu medzi účast'ou a populačnou vel'kost'ou obcí však boli mestá Košice a Bratislava hodnotené vždy ako celok, a to pre rešpektovanie ich pozície v sídelnej hierarchii Slovenska.

Údaje o volebnej účasti na úrovni obcí boli získané z databázy Slovenského archívu sociálnych dát (Krivý 2016). Nezávislé premenné boli vybrané tak, aby sa vzt'ahovali na tie aspekty sociálnej štruktúry a polohy obcí, s ktorými pracujú spomenuté teórie volebnej účasti. K zabráneniu multikolinearity nezávislých premenných boli použité dve metódy. Najskôr boli na základe korelačnej analýzy vylúčené premenné s vysokou párovou koreláciou s niektorou d'alšou nezávislou premennou. Následne bolo testom multikolinearity overené, že žiadna z nezávislých premenných nemá hodnotu tolerancie menšiu ako 0,2 ani hodnotu faktoru zvyšujúceho rozptyl (VIF) vyššiu než 5 (Rabušic 2004).

Vybraných bolo celkovo devät' nezávislých premenných. Podiel uchádzačov o zamestnanie z počtu obyvatel'ov vo veku 15 až 64 rokov (skratka NEZAM) a podiel obyvatel'ov s vysokoškolským vzdelaním (VŠ) boli zvolené na testovanie platnosti teórie sociálno-ekonomického statusu. Na overenie vypovedajúcej schopnosti teórie mobilizácie boli zaradené ukazovatele náboženského a národnostného stavu obyvatel'stva, a to podiel obyvatel'ov hlásiacich sa $k$ rímskokatolickej cirkvi (RIMKAT), podiel obyvatel'ov mad'arskej národnosti (MADARI) a podiel obyvatel'ov rómskej národnosti (RÓMOVIA). Podiel obyvatel’ov v poproduktívnom veku (POPROD) bol zvolený ako ukazovatel' relevantný pre verifikáciu teórie habituálneho hlasovania. Hrubá miera migračného salda (MSALDO) vypovedá o atraktívnosti miesta a $\mathrm{v}$ analýzach slúži ako citlivý ukazovatel' geografickej polohy. Bola vypočítaná ako rozdiel prist’ahovaných a vyst’ahovaných na 1000 obyvatel'ov obce, a to vždy ako priemer roku, v ktorom sa konali vol’by, a predchádzajúcich dvoch rokov.

Miera indukovanej potratovosti (POTR) a hrubá miera rozvodovosti (ROZVOD) boli zaradené jednak preto, že indikujú obce s vyšším výskytom sociálne problémových javov, čo môže poukazovat' na oblasti s vyššou koncentráciou negatívnych dosahov postsocialistickej transformácie (a potenciálne silnejším efektom sklamaného voliča), jednak preto, že Kostelecký (2001) preukázal vplyv týchto ukazovatel'ov na volebnú účast' na Slovensku v 90. rokoch.

Zdrojom dát o sociálnej štruktúre boli databázy Štatistického úradu Slovenskej republiky vychádzajúce zo sčítania obyvatel'stva (ŠÚ SR 2001 a 2011) alebo z priebežnej evidencie (ŠÚ SR 2017a, 2017b a 2017c). Na analýzu volebnej účasti vo vol'bách v rokoch 1998, 2002 a 2006 boli použité dáta zo sčítania obyvatel'stva z roku 2001. Pre vol'by z rokov 2010, 2012 a 2016 boli použité dáta zo sčítania z roku 2011. Zo sčítania obyvatel'stva boli získané údaje o náboženskej (RIMKAT), vzdelanostnej (VŠ) a národnostnej štruktúre obyvatel'stva (MAĎARI a RÓMOVIA). Pri ostatných údajoch, ktoré sú dostupné každoročne (NEZAM, POPROD, MSALDO, POTR a ROZV), boli vypočítané ich trojročné priemery, a to ako priemer roku, v ktorom sa konali vol'by, a predchádzajúcich dvoch rokov. 


\section{VÝSLEDKY}

Z regresných modelov vyplýva, že vo všetkých vol'bách v období rokov 1998 až 2016 bol dôležitým faktorom vysvetl'ujúcim výšku volebnej účasti podiel l’udí vo veku 65 a viac rokov (vid' tab. 1 a 2). S rastom podielu l'udí v poproduktívnom veku rástla aj volebná účast'. Od roku 2010 sa však absolútne hodnoty štandardizovaného regresného koeficientu (beta) pre podiel seniorov znižovali, čo pri súčasnom raste koeficientu determinácie regresných modelov naznačuje, že význam tejto premennej pri vysvetl'ovaní geografickej variability volebnej účasti v porovnaní s inými premennými klesal. Naopak, význam d'alšej premennej, pozitívne ovplyvňujúcej výšku volebnej účasti - podielu osôb hlásiacich sa $\mathrm{k}$ rímskokatolíckej cirkvi časom narástol. Až na vol'by v roku 1998 kladne ovplyvňoval volebnú účast' i podiel obyvatel'ov s vysokoškolským vzdelaním v obci. Nízka volebná účast' je spojená s vysokou nezamestnanost’ou, avšak význam tejto premennej v porovnaní s d’alšími indikátormi nie je príliš vel'ký.

Tab. 1. Výsledky regresných analýz pre volebnú účast' vo vol'bách v rokoch 1998 až 2006

\begin{tabular}{lcccccc}
\hline \multirow{2}{*}{ Premenné } & \multicolumn{2}{c}{ Vol'by v roku 1998} & \multicolumn{2}{c}{ Vol'by v roku 2002 } & \multicolumn{2}{c}{ Vol'by v roku 2006 } \\
\cline { 2 - 7 } & beta & $\mathrm{p}$ & beta & $\mathrm{p}$ & beta & $\mathrm{p}$ \\
\hline PNO & $-0,19$ & 0,00 & $-0,16$ & 0,00 & $-0,07$ & 0,00 \\
RIMKAT & 0,07 & 0,00 & 0,14 & 0,00 & 0,15 & 0,00 \\
VŠ & $-0,11$ & 0,00 & 0,09 & 0,00 & 0,16 & 0,00 \\
MAĎARI & 0,25 & 0,00 & 0,09 & 0,00 & 0,21 & 0,00 \\
RÓMOVIA & $-0,16$ & 0,00 & $-0,27$ & 0,00 & $-0,19$ & 0,00 \\
POPROD & 0,23 & 0,00 & 0,30 & 0,00 & 0,35 & 0,00 \\
MSALDO & 0,00 & 0,93 & 0,00 & 0,81 & 0,07 & 0,00 \\
ROZVOD & $-0,18$ & 0,00 & $-0,11$ & 0,00 & $-0,12$ & 0,00 \\
POTR & 0,05 & 0,08 & $-0,01$ & 0,52 & 0,03 & 0,06 \\
& $\mathrm{R}^{2}$ & 0,27 & $\mathrm{R}^{2}$ & 0,32 & $\mathrm{R}^{2}$ & 0,32 \\
\hline
\end{tabular}

Zdroj dát: Krivý (2016).

Tab. 2. Výsledky regresných analýz pre volebnú účast' vo vol'bách v rokoch 2010 až 2016

\begin{tabular}{lcccccc}
\hline \multirow{2}{*}{ Premenné } & \multicolumn{2}{c}{ Vol'by v roku 2010} & \multicolumn{2}{c}{ Vol'by v roku 2012} & \multicolumn{2}{c}{ Vol'by v roku 2016 } \\
\cline { 2 - 7 } & beta & $\mathrm{p}$ & beta & $\mathrm{p}$ & beta & $\mathrm{p}$ \\
\hline PNO & $-0,11$ & 0,00 & $-0,15$ & 0,00 & $-0,19$ & 0,00 \\
RIMKAT & 0,19 & 0,00 & 0,23 & 0,00 & 0,22 & 0,00 \\
VŠ & 0,30 & 0,00 & 0,11 & 0,00 & 0,26 & 0,00 \\
MAĎARI & 0,24 & 0,00 & $-0,14$ & 0,00 & $-0,21$ & 0,00 \\
RÓMOVIA & $-0,09$ & 0,00 & $-0,18$ & 0,00 & $-0,21$ & 0,00 \\
POPROD & 0,35 & 0,00 & 0,27 & 0,00 & 0,21 & 0,00 \\
MSALDO & 0,17 & 0,00 & 0,17 & 0,00 & 0,24 & 0,00 \\
ROZVOD & $-0,07$ & 0,00 & $-0,13$ & 0,00 & $-0,11$ & 0,00 \\
POTR & $-0,04$ & 0,01 & $-0,03$ & 0,04 & $-0,04$ & 0,00 \\
& $\mathrm{R}^{2}$ & 0,39 & $\mathrm{R}^{2}$ & 0,38 & $\mathrm{R}^{2}$ & 0,54 \\
\hline
\end{tabular}

Zdroj dát: Krivý (2016). 
Volebná účast' bola nízka $\mathrm{v}$ obciach $\mathrm{s}$ vysokým zastúpením rómskej menšiny. $\mathrm{Z}$ agregovaných dát samozrejme nemôžeme odvodit', či Rómovia chodia volit' menej často ako iní, ale iba to, že vyšší podiel obyvatel'ov hlásiacich sa k rómskej národnosti znamená vyššiu pravdepodobnost' volebnej neúčasti. V obciach s vysokým podielom obyvatel'ov mad'arskej národnosti bola do roku 2010 volebná účast' vysoká, avšak v posledných dvoch vol'bách došlo k otočeniu znamienka štandardizovaných regresných koeficientov a prítomnost' Mad'arov v obci je spojená s podpriemernou účast'ou.

Migračné saldo nemalo do roku 2006 na výšku volebnej účasti vplyv, potom však význam tejto charakteristiky geografickej polohy narástol: migračne atraktívne obce vykazujú nadpriemernú účast'. Index indukovanej potratovosti mal na vysvetlenie variability volebnej účasti len zanedbatel'ný vplyv. Hrubá miera rozvodovosti dokázala prispiet' $\mathrm{k}$ vysvetleniu variability o niečo viac, ale aj jej prínos bol nižší v porovnaní s premennými vyjadrujúcimi národnost', náboženské vyznanie, vekovú štruktúru alebo vzdelanie.

Dôležitým zistením je to, že postupom času dochádzalo k zvyšovaniu podielu variability závisle premennej vysvetlenej regresným modelom, čo je indikované nárastom koeficientu determinácie $\left(\mathrm{R}^{2}\right)$. Regresné modely s vyšším koeficientom determinácie majú vyššiu vypovedaciu schopnost', čo svedčí o tom, že mapa volebnej účasti v obciach Slovenska, respektíve rozdiely medzi obcami, sa v čase stávali viac podmienené sledovanými sociálno-ekonomickými indikátormi.

Regresné modely, prezentované v tabul'kách 1 a 2 , predstavujú výsledky analýzy, do ktorej boli zahrnuté všetky obce Slovenska. Nie je však možné, že i faktory podmieňujúce výšku volebnej účasti sú regionálne diferencované, teda, že rozdielna volebná účast' má v jednotlivých regiónoch Slovenska iné podmienenosti? $\mathrm{Na}$ zodpovedanie tejto otázky sme zopakovali regresné analýzy s rovnakými premennými nezávisle $\mathrm{v}$ troch oblastiach Slovenska: západné Slovensko (Bratislavský, Trnavský, Trenčiansky a Nitriansky kraj), stredné Slovensko (Žilinský a Banskobystrický kraj) a východné Slovensko (Prešovský a Košický kraj). V tab. 3 sú prezentované výsledky tejto analýzy pre vol'by v roku 2016.

Tab. 3. Výsledky regresných analýz pre volebnú účast' v roku $2016 \mathrm{v}$ troch regiónoch Slovenska

\begin{tabular}{lcccccc}
\hline \multirow{2}{*}{ Premenné } & \multicolumn{2}{c}{ Západné Slovensko } & \multicolumn{2}{c}{ Stredné Slovensko } & \multicolumn{2}{c}{ Východné Slovensko } \\
\cline { 2 - 7 } & beta & $\mathrm{p}$ & beta & $\mathrm{p}$ & beta & $\mathrm{p}$ \\
\hline PNO & $-0,17$ & 0,00 & $-0,26$ & 0,00 & $-0,17$ & 0,00 \\
RIMKAT & 0,27 & 0,00 & 0,27 & 0,00 & 0,18 & 0,00 \\
VŠ & 0,39 & 0,00 & 0,25 & 0,00 & 0,10 & 0,00 \\
MAĎARI & $-0,26$ & 0,00 & $-0,14$ & 0,00 & $-0,11$ & 0,00 \\
RÓMOVIA & $-0,21$ & 0,00 & $-0,09$ & 0,01 & $-0,26$ & 0,00 \\
POPROD & 0,13 & 0,00 & 0,16 & 0,00 & 0,32 & 0,00 \\
MSALDO & 0,30 & 0,00 & 0,22 & 0,00 & 0,12 & 0,00 \\
ROZVOD & $-0,08$ & 0,00 & $-0,18$ & 0,00 & $-0,12$ & 0,00 \\
POTR & $-0,03$ & 0,20 & $-0,05$ & 0,04 & 0,01 & 0,72 \\
& $\mathrm{R}^{2}$ & 0,62 & $\mathrm{R}^{2}$ & 0,49 & $\mathrm{R}^{2}$ & 0,46 \\
\hline
\end{tabular}

Zdroj dát: Krivý (2016). 
Hlavným záverom tejto analýzy je potvrdenie vysokej podobnosti faktorov podmieňujúcich volebnú participáciu v troch vymedzených regiónoch. Všetky tri regresné modely sú si podobné a súčasne sú podobné regresnému modelu pre celé Slovensko v roku 2016. Charakter vzt’ahu medzi závislou premennou (volebná účast') a nezávislými premennými, vyjadrený znamienkom pred hodnotou štandardizovaného regresného koeficientu, je vo všetkých prípadoch rovnaký, líši sa iba tesnost' týchto vzt'ahov. V porovnaní s týmto záverom majú rozdiely medzi regiónmi, uvedené v nasledujúcom odseku, len sekundárny význam.

Na západnom Slovensku vysvetl'ujú sociálno-ekonomické premenné geografickú variabilitu volebnej účasti viac ako na strednom a východnom Slovensku (vyššia hodnota koeficientu determinácie). Výška volebnej účasti v obciach západného Slovenska najviac súvisí s migračnou atraktivitou a vzdelanost'ou a negatívne tiež s podielom Mad'arov a podielom Rómov. Na strednom Slovensku je to najviac katolícke vierovyznanie a vzdelanost', a v negatívnom smere nezamestnanost', zatial' čo na východnom Slovensku - kde naopak nezamestnanost' má menší vplyv je to podiel Rómov. Podiel rímskych katolíkov je významnou premennou vo všetkých regiónoch, rovnako ako podiel seniorov; príspevok poslednej spomínanej premennej k vysvetleniu variability volebnej účasti rastie smerom na východ; v rovnakom smere klesá vplyv vzdelanosti a atraktivity polohy obce (reprezentovanej migračným saldom).

Premennou, ktorej vplyv na vysvetlenie variability volebnej účasti sa v priebehu dvoch desat'ročí najviac zmenil, bol podiel Mad'arov. Preto bol vzt'ah týchto dvoch premenných preskúmaný podrobnejšie. Obce boli rozdelené do piatich kategórií podl'a podielu obyvatel'stva mad'arskej národnosti a pre každú kategóriu bola vypočítaná priemerná volebná účast' $\mathrm{v}$ danom roku. Tá bola následne formou indexu porovnaná $\mathrm{s}$ národným priemerom $\mathrm{v}$ daných vol'bách (národný priemer $=1,0$ ). Výsledok tohto porovnania približuje obr. 5 .

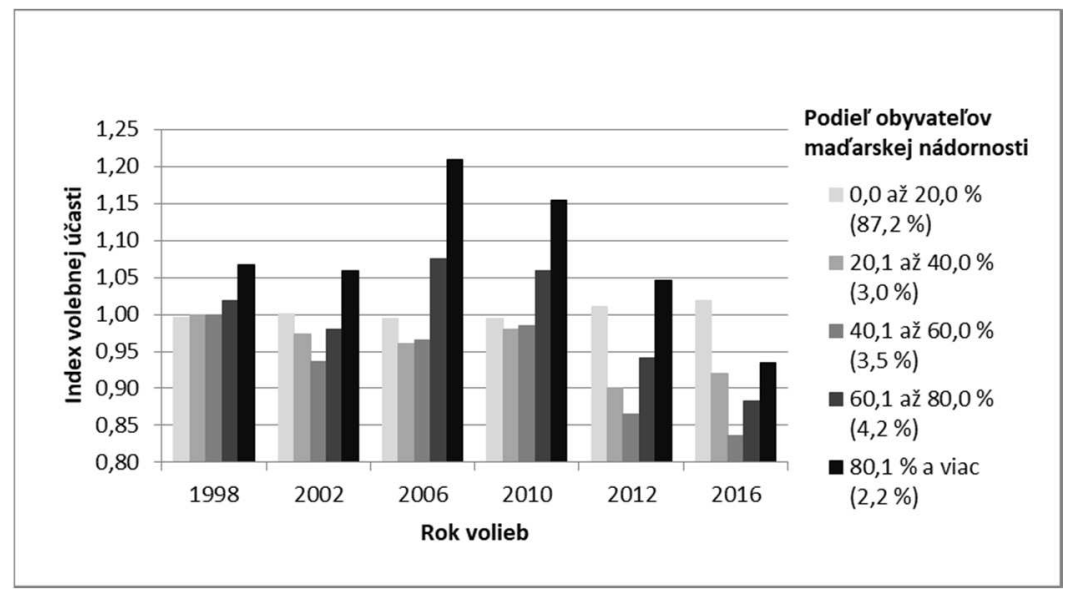

Obr. 5. Index volebnej účasti v parlamentných vol'bách v kategóriách obcí vymedzených na základe podielu mad'arského obyvatel'stva (číslo v zátvorke udáva podiel kategórie na úhrne voličov na Slovensku)

Zdroj dát: Krivý (2016) 
Do roku 2012 sa obce s vysokým podielom mad'arského obyvatel'stva vyznačovali i nadpriemernou volebnou účast'ou. Svedčí to o mobilizácii mad'arských voličov. Vyššia účast' v obciach s obyvatel'stvom prevažne mad'arskej národnosti bola pravdepodobne podmienená práve ich politickou mobilizáciou. Tá bola markantná vo vol'bách v rokoch 2006 a 2010. Odvtedy však výrazne klesla a v roku 2016 bola v obciach, kde žije viac ako 80 \% mad'arského obyvatel'stva, prvýkrát v rámci skúmaných volieb účast' nižšia ako v kategórií obcí s nízkym zastúpením mad'arského obyvatel'stva. Súčasne platí, že čím vyšší podiel mad'arského obyvatel'stva, tým výraznejší pokles volebnej participácie vo vol'bách v rokoch 2012 a 2016.

Teória sociálno-ekonomického statusu a teória modernizácie predpokladajú väčšiu volebnú účast' vo vel'kých mestách. To však nesúhlasí so zisteniami Kosteleckého (2001), ktorý zaznamenal práve v metropolitných regiónoch vel'mi nízku volebnú účast'. K tomu teória habituálneho hlasovania a zistenia Kosteleckého a Krivého (2015) predpokladajú vyššiu volebnú účast' v malých obciach, pretože l'udia v nich sú zvyknutí chodit' volit'. Vyššiu volebnú účast' v menších obciach predpokladá aj teória mobilizácie, pretože $\mathrm{v}$ menších obciach sú voliči viac pod sociálnou kontrolou svojho okolia a tým je na nich vyvíjaný väčší tlak zúčastnit' sa volieb (Linek 2013).

Na overenie vzt'ahu medzi populačnou vel'kost'ou obce a volebnou účast'ou boli obce Slovenska rozdelené do desiatich vel'kostných kategórií. Pre každú z nich bola vypočítaná volebná účast' a následne index volebnej účasti, porovnávajúci účast' v kategórii s národným priemerom (vid' tab. 4). Najvyššia hodnota indexu bola trvalo v najmenších obciach a s rastom počtu obyvatel'ov obce klesala. Najnižšia participácia bola v mestách s 10000 až 49999 obyvatel'mi. Vo väčších mestách index opätovne narastá. To potvrdzuje zistenia predošlých autorov, popisujúcich vzt'ah populačnej vel'kosti a volebnej participácie ako krivku tvaru písmena U (Krivý 2012 a Kostelecký a Krivý 2015).

Tab. 4. Index volebnej účasti vel'kostných kategórií obcí v rokoch 1998 až 2016 $($ Slovensko $=\mathbf{1 , 0})$

\begin{tabular}{ccccccc}
\hline $\begin{array}{c}\text { Vel'kostná kategória } \\
\text { (počet obyvatel'ov) }\end{array}$ & 1998 & 2002 & 2006 & 2010 & 2012 & 2016 \\
\hline \cline { 2 - 7 } $0-199$ & 1,06 & 1,10 & 1,17 & 1,15 & 1,12 & 1,09 \\
$200-499$ & 1,05 & 1,06 & 1,10 & 1,07 & 1,07 & 1,04 \\
$500-999$ & 1,03 & 1,03 & 1,04 & 1,03 & 1,03 & 1,01 \\
$1000-1999$ & 1,02 & 1,02 & 1,03 & 1,02 & 1,03 & 1,00 \\
$2000-4999$ & 1,00 & 0,99 & 0,99 & 0,98 & 1,00 & 0,98 \\
$5000-9999$ & 1,00 & 0,98 & 0,97 & 0,97 & 0,96 & 0,96 \\
$10000-19999$ & 0,97 & 0,96 & 0,94 & 0,95 & 0,95 & 0,95 \\
$20000-49999$ & 0,98 & 0,97 & 0,95 & 0,95 & 0,95 & 0,95 \\
$50000-99999$ & 0,99 & 1,01 & 1,01 & 1,02 & 1,02 & 1,05 \\
$100000+$ & 0,98 & 1,01 & 1,00 & 1,03 & 1,02 & 1,07 \\
\hline Variačnýy koeficient (v \%) & 3,08 & 4,42 & 7,39 & 6,28 & 5,72 & 5,04 \\
\hline Zdroj dát: Krivý (2016). & & & & & &
\end{tabular}


Napriek rámcovému zachovaniu tvaru došlo vo vzt'ahu participácie a populačnej vel'kosti $\mathrm{k}$ významným zmenám. Rozdiely medzi kategóriami sa od volieb v roku 1998 do roku 2006 zvyšovali (nárast hodnoty variačného koeficientu). Bolo to vyvolané významne rýchlejším poklesom účasti v stredne vel'kých mestách (s 5 až 50-tisícmi obyvatel'ov) v porovnaní s menšími, prevažne vidieckymi obcami. Počínajúc vol'bami v roku 2006 sa však rozdiely medzi kategóriami znižujú. Hlavnou príčinou bolo zníženie participácie vo vidieckych obciach, ktorá sa priblížila národnému priemeru. To malo na celkovú úroveň vertikálnej diferenciácie väčší vplyv než nárast $\mathrm{v}$ najväčších mestách, v ktorých bola v roku 2016 účast' rovnako nadpriemerná ako v najmenších vel'kostných kategóriách. Naznačuje to polarizáciu medzi modernizáciou podmienenou participáciou v najväčších mestách a slabnúcou rolou sociálnej kontroly a habituálneho hlasovania v malých vidieckych obciach.

\section{DISKUSIA}

Prvá hypotéza overovala platnost' teórie modernizácie, teórie sociálno-ekonomického statusu a teórie sklamaného voliča a opierala sa o ukazovatele vzdelanosti, migračnej atraktivity a nezamestnanosti. Analýza empirických dát preukázala, že vyšší podiel vysokoškolsky vzdelaných vždy, s výnimkou špecifických volieb v roku 1998, pozitívne ovplyvňoval volebnú účast', a význam tohto indikátora $\mathrm{v}$ regresných modeloch postupne narastal. Ešte vo vol'bách v roku 2002 bola absolútna hodnota beta tejto premennej málo významná, ale v roku 2010 už bola druhá najvyššia a v roku 2016 vôbec najvyššia medzi sledovanými ukazovatel'mi. Od roku 2006 sa medzi premennými, ktoré úspešne vysvetlujú geografickú variabilitu volebnej účasti, presadila aj hrubá miera migračného salda, ktorú interpretujeme ako ukazovatel' polohovej atraktivity obce. Tá sa v roku 2016 stala absolútnou hodnotou štandardizovaného regresného koeficientu druhou najvplyvnejšou premennou (tab. 2). Vo všetkých šiestich sledovaných vol'bách tiež platilo, že vyššia volebná účast' bola v obciach s nižšou mierou nezamestnanosti, ale vplyv miery nezamestnanosti bol $\mathrm{v}$ porovnaní $\mathrm{s}$ predchádzajúcimi dvoma premennými slabší a $\mathrm{v}$ čase viac kolísal.

S teóriou modernizácie korešponduje aj vyššia volebná účast' v ekonomicky rozvinutejších regiónoch, akým je Bratislava a jej okolie. Ked' tieto zistenia porovnáme s výsledkami Kosteleckého (2001), ktorý skúmal volebnú účast' v 90. rokoch, vidno transformáciu metropolitných regiónov $\mathrm{z}$ oblastí $\mathrm{s}$ vysokou neúčastou na oblasti s vysokou účast'ou. V 90. rokoch, ked' bola v regiónoch s vyššou priemernou mzdou volebná účast' nižšia, bolo možné jej regionálnu premenlivost' vysvetl'ovat' prostredníctvom teórie sklamaného voliča. Premena mapy volebnej účasti spolu s premenou faktorov, ktoré tuto mapu vysvetl'ujú, tak presvedčivo podporujú názor Nového (2013), ktorý tvrdí, že v postsocialistických krajinách došlo k zmene vo vysvetl'ovaní podmienenosti volebnej účasti, pretože v 90 . rokoch mala väčšiu vypovedaciu schopnost' teória sklamaného voliča, ale neskoršie vol'by čoraz viac potvrdzujú platnost' teórie modernizácie. Vel'kost' mesta a d'alšie ukazovatele polohovej atraktivity, ako je migračné saldo a nepriamo i podiel vysokoškolákov, tak získali významný pozitívny vplyv na úroveň volebnej účasti. Skutočnost’ou, ktorá obmedzuje výpovednú schopnost' teórie modernizácie pri interpretácii mapy volebnej participácie na Slovensku, je nízka účast' v druhom najväčšom slovenskom meste - v Košiciach. Tá je podstatne nižšia, ako by podl'a teórie zodpovedala centru jeho vel'kosti a významu. Aj v Košiciach je však účast' vyššia ako vo zvyšku Košického kraja a od roku 2012 sa viac približuje slovenskému priemeru ako Ko- 
šickému kraju. Nízku účast' v Košiciach je tak čiastočne možné vysvetlit' oneskoreným prechodom od modelu sklamaného voliča $\mathrm{k}$ modernizačnému modelu. Istú úlohu však môže hrat' aj efekt hlavného mesta, ktorý podporuje nárast participácie v Bratislave viac ako zodpovedá jej migračnému saldu alebo vzdelanostnej štruktúre, aj efekt prostej geografickej vzdialenosti, ktorý môže viest' niektorých voličov v Košiciach k názoru, že parlament je príliš d'aleko a možnost' ovplyvnit' jeho rozhodnutia príliš nízka, než aby sa oplatilo íst' volit'.

Transformácia od špecificky postsocialistického modelu sklamaného voliča k tradičnejšej explanácii založenej na stupni modernizácie tak prebieha geograficky nerovnomerne, čo ukazujú odlišné tvary regresných modelov pre tri slovenské regióny. Dvoma premennými, ktoré v roku 2016 najviac vysvetl'ovali variabilitu účasti (merané absolútnou hodnotou štandardizovaného regresného koeficientu), boli na západnom Slovensku podiel vysokoškolsky vzdelaných a saldo migrácie, na strednom Slovensku miera nezamestnanosti a podiel veriacich katolíkov a na východnom Slovensku podiel seniorov a Rómov (tab. 3).

Druhá hypotéza overovala platnost' teórie mobilizácie, konkrétne otázky, či príslušnost' k určitému vnímanému spoločenstvu, vzniknutému na základe vyznania, národnej identity alebo lokality, môže mobilizovat' na volebnú participáciu. Výsledky potvrdili nadpriemerne vysokú volebnú účast' v najmenších obciach, čo zodpovedá mobilizácii občanov z dôvodu sociálnej kontroly v rámci obce, ako to predpokladal Knack (1992). Regresné modely ukázali vysokú účast' v obciach s vyšším podielom l'udí vyznávajúcich rímskokatolícku vieru. Táto premenná sa pozitívne presadila vo všetkých regresných modeloch, pričom počínajúc vol'bami 2006 bola jej absolútna hodnota beta vždy vyššia ako 0,2. Naproti tomu mobilizácia voličov v obciach s vyšším podielom Mad'arov v sledovanom období výrazne poklesla. Zatial' čo vo vol'bách roku 1998 bol podiel Mad’arov najvýznamnejší prediktor volebnej účasti a ešte v roku 2010 tretí najvýznamnejší, v posledných dvoch vol'bách vidno v obciach s vysokým podielom mad'arskej menšiny známky rezignácie z participácie vo vol'bách, čo indikuje výrazne podpriemerná volebná účast' (a záporné hodnoty regresných koeficientov - tab. 2).

Tento trend zaznamenal už Krivý (2012) medzi parlamentnými vol'bami v rokoch 2010 a 2012 a udáva pre neho niekol'ko dôvodov. Jedným z nich je rozštiepenie dovtedy jedinej mad'arskej politickej strany SMK na tradične zameranú stranu SMK a stranu Most-Híd, ktorá sa snaží presadzovat' politiku spolupráce národnostných menšín na Slovensku. Výsledok volieb v roku 2010, ked' sa do parlamentu dostala len strana Most-Híd, mohol viest' niektorých voličov SMK k nezáujmu o politický proces, lebo ich preferovaná strana SMK nemala šancu dostat' sa do parlamentu a oni neboli ochotní volit' druhú stranu mad'arskej menšiny. Ako druhý dôvod poklesu volebnej účasti $\mathrm{v}$ obciach $\mathrm{s}$ významným zastúpením občanov mad’arskej národnosti býva označované oslabovanie ,slovensko-mad’arskej konfliktnej línie“ (Szabó a Tátrai 2016).

Naproti tomu podiel Rómov mal po celé obdobie na výšku volebnej účasti štatisticky významný negatívny vplyv. Vo vol'bách v roku 2002 to bol druhý najsilnejší prediktor výšky účasti a ešte v roku 2016 tretí najsilnejší. Zdá sa, že v obciach s vyšším zastúpením rómskej populácie zostáva dlhodobo nízky záujem o volebnú participáciu. V kontexte poukázania na riziko ekologickej chyby a relatívne nízky podiel l'udí, ktorí sa v sčítaní obyvatel'stva hlásia k rómskej národnosti, je však možné, že premenná podiel Rómov môže byt' zástupnou premennou pre pôsobenie iného faktora geografickej diferenciácie, napríklad miery chudoby. 
Tretia hypotéza overovala platnost' teórie habituálneho hlasovania. Predpokladala, že starší l'udia sú zvyknutí chodit' volit' vd'aka návyku z obdobia socializmu (Linek 2013). Regresné modely pozitívny vplyv podielu seniorov v obci na volebnú účast' presvedčivo potvrdili. Vo vol'bách v rokoch 2002 až 2012 bol podiel seniorov vôbec najvýznamnejším prediktorom volebnej účasti a významný zostal i v roku 2016, aj ked' v poradí klesol na štvrté miesto. Zvlášt' silný vzt'ah medzi participáciou a vekovou štruktúrou obyvatel'ov obce bol v roku 2016 na východnom Slovensku, ale významný bol i v iných regiónoch. Pre platnost' teórie habituálneho hlasovania na Slovensku hovorí aj zvýšená volebná účast' v najmenších obciach. Súčasne je však treba pripomenút', že vo vekovej štruktúre sa odráža aj vplyv iných faktorov, ako je napríklad vzdelanostná štruktúra, geografická poloha či práve vel'kost' obce a vzt'ah medzi volebnou participáciou a vekom preto nie je nezávislý na iných podmieňujúcich faktoroch. V tomto zmysle musíme empirickú verifikáciu všetkých uvedených hypotéz považovat' za sprostredkovanú a podmienenú aj inými faktormi okrem tých, ktoré hypotézu podporujú.

\section{ZÁVER}

Jednoduchá geografická analýza jedinej premennej volebného správania odhalila významné premeny, ktoré v uplynulých dvoch desat'ročiach prebiehali v slovenskej spoločnosti. Volebná participácia sa stala lepšie vysvetlitel'ná a predpovedatel'ná sociálnou štruktúrou a geografickou polohou obce, čo dokladá nárast vypovedacej schopnosti regresných modelov. Zatial' čo v roku 1998 dokázali nezávislé premenné vysvetlit' len $27 \%$ variability volebnej účasti (hodnota indexu determinácie), v roku 2016 to bolo už $52 \%$. Pomerne náhodné rozmiestnenie obcí s vysokou a nízkou participáciou sa tým stalo viac podmienené polohou a sociálnou štruktúrou. K nárastu vypovedajúcej schopnosti regresných modelov prispelo i celkové zvýšenie regionálnej variability účasti, nech už ju meriame v akejkol'vek geografickej mierke (kraj, okres a obec). Súčast'ou prehĺbenia regionálnych rozdielov bolo ich zväčšenie medzi východom a západom krajiny. Zjednodušene povedané, na západ od línie Vysoké Tatry - Šahy prevažujú obce s nadpriemernou participáciou, zatial' čo na východ od nej je to naopak.

Hlavným ciel'om analýzy bolo empiricky overit' vypovedajúcu schopnost' piatich teórií volebnej účasti. Ukázalo sa, že pre vysvetlenie mapy volebnej participácie sú všetky relevantné, ale rôznou mierou, a ich interpretačný prínos sa v čase mení. Zatial' čo v 90. rokoch a začiatkom nultých rokov bola relevantná teória sklamaného voliča, čo indikoval slabý vzt’ah medzi výškou participácie a sociálnou štruktúrou i nízka volebná účast' vo vel'kých mestách, v súčasnom desat'ročí sa výška volebnej účasti stala významne podmienenou atraktivitou geografickej polohy, ktorú $\mathrm{v}$ analýze vyjadrovalo migračné saldo i podiel vysokoškolsky vzdelaných. To zodpovedá teórii modernizácie i teórii sociálno-ekonomického statusu. Na vplyv nepriamej mobilizácie $\mathrm{v}$ rámci komunity poukazuje významný pozitívny vzt’ah medzi participáciou a rímskokatolíckym vyznaním, ktorý bol stabilne silný vo všetkých vol'bách od roku 2006. Naopak, s rastom podielu Rómov v obci volebná účast' klesá. To môže indikovat' rezignáciu Rómov na snahu o kolektívne presadenie záujmov prostredníctvom volieb, no môže to indikovat' rovnakú rezignáciu osôb žijúcich v chudobe alebo iných sociálnych skupín, rozmiestených na Slovensku podobne ako Rómovia. Mapa volebnej účasti v parlamentných vol'bách v rokoch 2012 a 2016 naznačuje, že k podobnej rezignácii môže dochádzat' i v obciach s vyšším zastúpením obyvatel'ov mad'arskej národnosti, aj ked' tu sa ponúkajú tiež 
iné vysvetlenia. Na vypovedaciu schopnost' teórie habituálneho hlasovania pri interpretácii mapy volebnej účasti Slovenska poukazuje vysoká účast' v malých obciach a silný pozitívny vzt'ah medzi účast'ou a podielom seniorov. Táto premenná sa $\mathrm{v}$ regresných modeloch presadila vôbec najviac a po prvýkrát vo vol'bách $\mathrm{v}$ roku 2016 ju z pozície najsilnejšieho prediktora odsunuli premenné podiel vysokoškolsky vzdelaných a migračné saldo.

Proces transformácie podmieneností volebného správania obyvatel'ov Slovenska pokračuje, ako to dokladajú čiastkové odlišnosti v podmienenosti volebnej participácie indikátormi sociálnej štruktúry $\mathrm{v}$ jednotlivých regiónoch. Vzhl'adom na nárast významu teórie modernizácie pri interpretácii mapy volebnej participácie je možné do budúcna očakávat's nárastom sociálno-ekonomických rozdielov medzi regiónmi aj nárast rozdielov v ochote zúčastnit' sa volieb. V každom prípade zostane participácia významná pre výsledok budúcich volieb a preto je dôležité venovat' jej pozornost'v geografickom výskume.

Príspevok vznikol v rámci projektu špecifického výskumu MUNI/A/1356/2019 , Výzkum proměn geografických procesů a vztahů v prostoru a čase. "

\section{LITERATÚRA}

BIRCH, S. (2003). Electoral systems and political transformation in post-communist Europe. Basingstoke (Palgrave).

BLAIS, A. (2000). To vote or not to vote. Pittsburgh (Pittsburgh University Press).

BRADY, H. E., VERBA, S., SCHLOZMAN, K. L. (1995). Beyond SES: A resource model of political participation. American Political Science Review, 89, 271-294. DOI: https:// doi.org/10.2307/2082425.

CAMPBELl, A., CONVERSE, P., MILLER, W. A., STOKES, D. (1960). The American voter. New York (Wiley).

DENNY, K., DOYLE, O. (2009). Does voting history matter? Analysing persistence in turnout. American Journal of Political Science, 53, 17-35. DOI: https://doi.org/10.1111/ j.1540-5907.2008.00355.x.

FIELDHOUSE, E. (2019). Being a voter: developing a survey instrument for expressive voting. Journal of Elections, Public Opinion and Parties, 29, 318-340. DOI: https:// doi.org/10.1080/17457289.2018.1530679.

FRANKLIN, M. N. (2004). Voter turnout and the dynamics of electoral competition in established democracies since 1945. Cambridge (Cambridge University Press).

GREEN, D. P., SHACHAR, P. (2000). Habit formation and political behaviour: evidence of consuetude in voter turnout. British Journal of Political Science, 30, 561-573. DOI: https://doi.org/10.1017/S0007123400000247.

GYÁRFÁŠOVÁ, O., KRIVÝ, V. (2013). Vzorce voličského správania. In Krivý, V., ed. Ako sa mení slovenská spoločnost'. Bratislava (Sociologický ústav SAV), pp. 257-342.

HENDL, J. (2012). Přehled statistických metod. A nalýza a metaanalýza dat. Praha (Portál).

JOHNSTON, R. J. (1987). Money and votes: Constituency campaign spending and election results. London (Croom Helm).

KNACK, S. (1992). Civic norms, social sanctions, and voter turnout. Racionality and Society, 4, 133-156. DOI: https://doi.org/10.1177/1043463192004002002.

KOSTADINOVA, T. (2003). Voter turnout dynamics in post-communist Europe. European Journal of Political Research, 42, 741-759. DOI: https://doi.org/10.1111/14756765.00102 .

KOSTELECKÝ, T. (2001). Vzestup nebo pád politického regionalismu? Změny na politické mapě v letech 1992 až 1998 - srovnáni České a Slovenské republiky. Praha (Sociologický ústav Akademie věd České republiky). 
KOSTELECKÝ, T., KRIVÝ, V. (2015). Urbánno-rurálne rozdiely voličského správania v Česku a na Slovensku. Sociológia, 47, 390-413.

KRIVÝ, V. (1999). Čo prezrádzajú volebné výsledky? Parlamentné vol’by 1992 - 1998. Bratislava (Inštitút pre verejné otázky).

KRIVÝ, V. (2012). Výsledky volieb '12: čo sa zmenilo, čo zostáva. In Krivý, V., ed. Slovenské vol'by '12: čo im predchádzalo, postoje a výsledky. Bratislava (Sociologický ústav SAV), pp. 47-136.

KRIVÝ, V. (2016). Výsledky volieb 1929 - 2016 za obce na Slovensku, [Online]. Dostupné na: http://sasd.sav.sk/sk/data katalog abs.php?id=sasd 2010001 [cit: 16-6-2017].

LIJPHART, A. (1997). Unequal participation: democracy's unresolved dilemma. American Political Science Review, 91, 1-14. DOI: https://doi.org/10.2307/2952255.

LINEK, L. (2013). Kam se ztratili voliči?: Vysvětlení vývoje volební účasti v České republice v letech 1990-2010. Brno (Centrum pro studium demokracie a kultury).

LINEK, L. (2015). Účast ve sněmovních volbách v roce 2013: zdroje, mobilizace a motivace. European Electoral Studies, 10, 76-90.

MADLENAK, T. (2012). Regionálna diferenciácia volebného správania na Slovensku (1998 - 2010). Bratislava (VEDA).

MADLEŇÁK, T., PINK, M. (2012). Základné priestorové vymedzenie voličskej základne politických strán na Slovensku 1994 - 2010. In Pink, M., ed. Volební mapy České a Slovenské republiky po roce 1993: vzorce, trendy, proměny. Brno (Centrum pro studium demokracie a kultury), pp. 47-88.

MIKUŠ, R. (2014). Politická diferenciácia územia Slovenska z pohl’adu volebných preferencií. In Lauko, V., ed. Regionálne dimenzie Slovenska. Bratislava (Univerzita Komenského), pp. 67-125.

MIKUŠ, R., GURNÁK, D. (2014). Špecifiká volebnej účasti v obciach Košického kraja vo vol'bách na rôznych úrovniach v rokoch 1999 - 2014. Geographia Cassioviensis, 8, $150-161$.

NORRIS, P. (2000). A virtuous circle: Political communications in postindustrial societies. Cambridge (Cambridge University Press).

NORRIS, P. (2002). Democratic phoenix: reinventing political activism. Cambridge (Cambridge University Press).

NOVÝ, M. (2013). Volební účast a její determinanty ve starých a nových demokraciích Evropy. Sociológia, 45, 195-228.

PACEK, A. C., POP-ELECHES, G., TUCKER, J. A. (2009). Disenchanted or discerning: voter turnout in post-communist countries. Journal of Politics, 71, 473-491. DOI: https://doi.org/10.1017/S0022381609090409.

PATTIE, C., HARTMAN, T. K., JOHNSTON, R. J. (2019). Not all campaigns are created equal: Temporal and spatial variability in constituency campaign spending effects in Great Britain, 1997-2015. Political Geography, 71, 36-46. DOI: https://doi.org/10.1016/ j.polgeo.2019.02.010.

PLESIVĆÁK, M., BUČEK, J., BAČÍK, V., KUSENDOVÁ, D. (2016). Theoretical and methodological notes on current options related to examination of voting behaviour The geographical approach. A cta Geographica Universitatis Comenianae, 60, 151-170.

RABUŠIC, L. (2004). Mnohonásobná lineární regrese, [Online]. Dostupné na: https:// is.muni.cz/el/1423/podzim2004/SOC418/multipl regres 1.pdf [cit: 6-11-2017].

ROSENSTONE, S. J., HANSEN, J. M. (2009). Mobilization, participation, and democracy in America. New York (Longman).

RYBÁ̌̆, M., SPÁČ, P., VODA, P., NEMČOK, M. (2017). Po stopách politického zemétreseni: parlamentni volby na Slovensku v roce 2016. Brno (Centrum pro studium demokracie a kultury).

SCHULZ-HERZENBERG, C. (2019). To vote or not? Testing micro-level theories of voter turnout in South Africa's 2014 general elections. Politikon, 46, 139-156. DOI: https:// doi.org/10.1080/02589346.2019.1595879.

SZABÓ, B., TÁTRAI, P. (2016). Regional and social cleavages in the Slovak elections after the change of the regime. Geografický časopis, 68, 195-212. 
ŠÚ SR (2001). Sčitanie obyvatel'ov, domov a bytov 2001. Bratislava (Štatistický úrad SR).

ŠÚ SR (2011). Sčitanie obyvatel'ov, domov a bytov 2011, [Online]. Dostupné na: https:// slovak.statistics.sk [cit: 22-10-2017].

ŠÚ SR (2017a). Evidovaní uchádzači o zamestnanie, [Online]. Dostupné na: http:// datacube.statistics.sk [cit: 22-10-2017].

ŠÚ SR (2017b). Indexy vekového zloženia, [Online]. Dostupné na: http://datacube. statistics.sk [cit: 22-10-2017].

ŠÚ SR (2017c). Pramenné dielo - Pohyb obyvatel'stva, [Online]. Dostupné na: https:// slovak.statistics.sk [cit: 22-10-2017].

VLACHOVÁ, K. (2012). Volební neúčast: kdo nešel k volbám? In Linek, L., ed. Voliči a volby 2010. Praha (Sociologicke nakladatelství), pp. 63-86.

WOLFINGER, R. E., ROSENSTONE, S. J. (1980). Who votes? New Haven (Yale University Press).

\section{Dominik Kevický, Petr Dan \\ WHERE DO VOTERS APPEAR AT BALLOTS? FACTORS INFLUENCING THE GEOGRAPHICAL DISTRIBUTION OF VOTER TURNOUT IN SLOVAK PARLIAMENTARY ELECTIONS}

The main objective of the research was to test the predictive ability of five voter turnout theories in the conditions of Slovak society (the societal modernization theory, the theory of disenchanted voting, the socioeconomic status theory, the mobilization theory and the theory of habitual voting). To test the predictive ability of theories, three hypotheses were formulated and verified using quantitative methods such as multiple regression analysis and additional univariate statistical analyses.

The results have shown that all five theories are relevant for the explanation of the map of electoral participation in Slovakia. However, the interpretative contribution of individual theories has changed over time. While the theory of disenchanted voting was very relevant for the explanation of regional differences in voter turnout in the 1990s and early 2000s, the societal modernization theory and the socioeconomic status theory gained more interpretative power in the 2010s. It was indicated by a significant contribution of independent variables such as the proportion of university graduates or the net migration rate to the regression models for turnout. The effect of mobilization theory has been observed in the case of a positive contribution of the variable "the share of Roman Catholics in municipality" to the regression models, which has been steadily rising since 2006. On the contrary, the share of Roma population in municipalities has been influencing the electoral turnout in a negative way. It can be interpreted as a sign of resignation on the opportunity to use elections to achieve collective objectives among the Roma community. However, the share of Roma population in municipalities can also be a proxy for some other variables, such as the poverty rate, thanks to the ecological fallacy of the regression models. The electoral turnout in the municipalities with Hungarian minority has changed significantly in the last two parliamentary elections (2012 and 2016), from regions with a significantly above-average turnout to regions with a below-average turnout. It can be explained, in part, by a split among political parties representing the Hungarian minority in Slovakia, following the mobilization theory. Finally, the high turnout in small municipalities and the significantly positive contribution of the share of seniors to regression models have proved the explanatory power of the habitual voting theory in contemporary Slovakia.

The process of transition of voter behaviour in Slovakia is geographically uneven, as is witnessed by a greater validity of modernization and socioeconomic status theories in the western regions and the theory of habitual voting and mobilization theory in the eastern 
regions. The explanation of regional and local differences in electoral participation is becoming more similar to models observed in the western European democracies. However, significant differences remain, which is one of the reasons for close observation of the electoral participation map of Slovakia in future geographical research.

Article first received: July 2019

Article accepted: March 2020 